\title{
LISTERIA SPP. ASSOCIATED TO DIFFERENT LEVELS OF AUTOCHTHONOUS MICROBIOTA IN MEAT, MEAT PRODUCTS AND PROCESSING PLANTS
}

\author{
Márcia de Aguiar Ferreira Barros ${ }^{1,2 *}$; Luís Augusto Nero³; Aline Villas-Bôas Manoel²; Loredana d'Ovídio²; \\ Lívia Cavaletti da Silva ${ }^{2}$; Bernadette Dora Gombossy de Melo Franco ${ }^{4}$; Vanerli Beloti ${ }^{2}$
}

${ }^{1}$ Faculdade de Agronomia e Medicina Veterinária, Universidade de Brasília, Brasília, DF, Brasil; ${ }^{2}$ Departamento de Medicina Veterinária Preventiva, Universidade Estadual de Londrina, Londrina, PR, Brasil; ${ }^{3}$ Departamento de Veterinária, Universidade Federal de Viçosa, Viçosa, MG, Brasil; ${ }^{4}$ Departamento de Alimentos e Nutrição Experimental, Faculdade de Ciências Farmacêuticas, Universidade de São Paulo, São Paulo, SP, Brasil

Submitted: September 15, 2006; Returned to authors for corrections: July 04, 2007; Approved: September $20,2007$.

\begin{abstract}
High levels of microbial contamination, commonly found in animal origin foods and food processing environments, are able to hinder the growth of pathogens in these products and interfere in the results of laboratory analyses for detection of these pathogens. With the aim of verifying the possible interference of the autochthonous microbiota encountered in meat and meat products and processing plants over the presence of Listeria spp., 443 samples, collected from 11 meat retail establishments, were submitted to microbiological analysis to determine the levels of mesophilic aerobes, total coliforms and Escherichia coli and the presence of Listeria spp., according to the methodology proposed by the USDA. The results did not show evident interference of the autochthonous microbiota over Listeria spp., once the genus was detected even in the meat, meat products and environmental samples with high levels of contamination by mesophilic aerobes and coliforms.
\end{abstract}

Key words: meat; Listeria spp., autochthonous microbiota

\section{INTRODUCTION}

Listeria monocytogenes emergence as a foodborne pathogen dates from 1980, with the occurrence of many outbreaks and sporadic cases of listeriosis associated with the consumption of contaminated foods $(3,7,20,28)$. The invasive form of this pathogen is considered too risky especially to newborns, elderly and immune-compromised individuals, who may present septicemia, encephalitis, meningitis and abortion, and high levels of mortality $(11,12,29)$. Among Listeria species, only L. monocytogenes is recognized as a human pathogen (7). Most foods are tested for the presence of non-pathogenic Listeria spp only, as an indication of the possible presence of $L$. monocytogenes $(5,6,26,30)$.

The occurrence of Listeria spp. and L. monocytogenes in foods is highly variable worldwide $(7,9,24)$. In many regions the reported occurrence is low, especially in foods with high levels of microbial contaminants $(15,16,24)$. According to Jay $(15,16)$, levels of contaminants higher than $10^{6} \mathrm{CFU} / \mathrm{g}$ create unsatisfactory conditions for the growth of pathogens in foods. The dynamic of the interference depends on the presence of specific antagonistic microorganisms and also on the ability of producing inhibitory substances.

In meat and meat products, the authochtonous microbiota, which includes the natural microbiota of beef and the contaminants determined by the hygienic procedures during slaughter and processing $(1,10,13,16,23,33)$, may include strains capable of producing a variety of antimicrobial compounds that may impair the survival or inhibit the growth of $L$. monocytogenes $(2,4,18,22)$. Moreover, the contaminants can also interfere on the effectiveness of the laboratory isolation and detection methods, leading to erroneous results about the presence of L. monocytogenes in the product (31).

*Corresponding Author. Mailing address: Faculdade de Agronomia e Medicina Veterinária, Universidade de Brasília, Campus Darcy Ribeiro, Caixa Postal 4508, 70910 970, Brasília, DF, Brasil. Tel.: +55 613307 2803, ramal 20. Fax: +55 613273 6593. E-mail: mafer@unb.br 
Several methodologies are available for isolation of Listeria spp. in foods. All methods employ enrichment phases at different temperatures using different supplements, selective agents and incubation conditions $(6,19,27,31)$. Selective enrichment steps are necessary to inhibit the growth of the competitive microbiota and optimize the multiplication of Listeria spp., leading to their amplification to required level for proper detection. As an example, the University of Vermont Listeria Enrichment broth (UVM), recommended by the United Stated Department of Agriculture (32), is an enrichment medium which contains nalidixic acid and acriflavine as supplements to inhibit Gram negative and Gram positive microorganisms, respectively. This culture medium is considered the most suitable for testing foods where high levels of competitive microbiota are expected $(25,30)$.

In beef, despite the occurrence of antagonistic microorganisms in the autochthonous microbiota $(2,4,16)$, there is no evidence of the direct interference of these microbiota on Listeria spp. isolation procedures $(6,21)$. The aim of this study was to verify the influence of the autochthonous microbiota in meat and meat products and in the meat processing environment on the detection of Listeria spp., using the detection protocol recommended by USDA (32).

\section{MATERIALAND METHODS}

\section{Samples and dilutions}

Eleven meat retail establishments (one slaughterhouse and ten butcher shops) located in Londrina region, north of Paraná State, Brazil, inspected by Brazilian Agriculture (the slaughterhouse) or Health (butcher shops) Authorities, were randomly selected. In these establishments, a total of 443 samples were taken (Table 1), comprising 148 surface samples collected from the equipments (knives, mincers, boxes, etc), 65 samples collected from the environment (drains, floors, etc) and 230 meat and meat product samples. Surface samples were obtained with sterile swabs and sterile templates to limit the specific area shown in Table 1 . Swabs were transferred to flasks containing $45 \mathrm{~mL}$ of $0.1 \%$ buffered peptone water (Oxoid, Basingstoke, UK). Meat samples were collected in sterile bags. The samples were kept under refrigeration during the transport to the laboratory. For testing, $10 \mathrm{~g}$ of the collected samples were weighted and transferred to $90 \mathrm{~mL}$ of $0.1 \%$ buffered peptone water (Oxoid, Basingstoke, UK), and homogenized with a stomacher. The homogenates were submitted to serial decimal dilutions using sterile $\mathrm{NaCl} 0.85 \%$. area.
Table 1. Points of sampling, number of samples and surface sampling

\begin{tabular}{|c|c|c|c|c|}
\hline \multirow[b]{2}{*}{ Samples } & \multirow[b]{2}{*}{$\begin{array}{c}\text { Sampled } \\
\text { area/quantity } \\
\mathrm{cm}^{2} \text { or g }\end{array}$} & \multicolumn{3}{|c|}{ Number of samples } \\
\hline & & $\begin{array}{c}\text { Butcher } \\
\text { shops } \\
n\end{array}$ & $\begin{array}{l}\text { Slaughter- } \\
\text { house } \\
n\end{array}$ & $\begin{array}{c}\text { Total } \\
\mathrm{n}\end{array}$ \\
\hline \multicolumn{5}{|l|}{ Equipments } \\
\hline Meat knives & $30 \mathrm{~cm}^{2}$ & 15 & 6 & 21 \\
\hline Meat mincers & $30 \mathrm{~cm}^{2}$ & 9 & 1 & 10 \\
\hline Meat mixers & $30 \mathrm{~cm}^{2}$ & 3 & 1 & 4 \\
\hline Meat saws & $30 \mathrm{~cm}^{2}$ & 10 & - & 10 \\
\hline Meat scales & $30 \mathrm{~cm}^{2}$ & 9 & - & 9 \\
\hline Meat tenderizers & $30 \mathrm{~cm}^{2}$ & 8 & - & 8 \\
\hline Plastic boxes & $30 \mathrm{~cm}^{2}$ & 26 & 2 & 28 \\
\hline Refrigerated trucks & $60 \mathrm{~cm}^{2}$ & 4 & - & 4 \\
\hline Sausage fillers & $30 \mathrm{~cm}^{2}$ & 2 & 1 & 3 \\
\hline Stainless steel boxes & $30 \mathrm{~cm}^{2}$ & 10 & - & 10 \\
\hline Stainless steel tables & $60 \mathrm{~cm}^{2}$ & 20 & 1 & 21 \\
\hline Steel hooks & Surface area & 7 & 3 & 10 \\
\hline Wood frames & $30 \mathrm{~cm}^{2}$ & 10 & - & 10 \\
\hline \multicolumn{5}{|l|}{ Environments } \\
\hline Drains & Surface area & 18 & 7 & 25 \\
\hline Floors & $60 \mathrm{~cm}^{2}$ & 9 & 1 & 10 \\
\hline Meat cabinets & $60 \mathrm{~cm}^{2}$ & 11 & - & 11 \\
\hline Reception platform & $60 \mathrm{~cm}^{2}$ & - & 5 & 5 \\
\hline Refrigeration systems & $60 \mathrm{~cm}^{2}$ & 4 & - & 4 \\
\hline Walls & $60 \mathrm{~cm}^{2}$ & 10 & - & 10 \\
\hline \multicolumn{5}{|l|}{ Products } \\
\hline Beef cuts & $50 \mathrm{~cm}^{2}$ & 51 & 1 & 52 \\
\hline Bovine carcasses & $50 \mathrm{~cm}^{2}$ & 142 & 9 & 151 \\
\hline Cooked sausages & $5 \mathrm{~g}$ & - & 2 & 2 \\
\hline Fresh sausages & $5 \mathrm{~g}$ & 10 & - & 10 \\
\hline Ground beef & $5 \mathrm{~g}$ & 12 & - & 12 \\
\hline Swine carcasses & $50 \mathrm{~cm}^{2}$ & - & 3 & 3 \\
\hline Total & & 400 & 43 & 443 \\
\hline
\end{tabular}

\section{Microbiological analysis}

The samples were tested for the presence of Listeria spp. according to the protocol proposed by USDA (32). In the preenrichment step, $5.0 \mathrm{~mL}$ of the peptone water containing the swab or $5.0 \mathrm{~g}$ of product were transferred to $45.0 \mathrm{~mL}$ of University of Vermont Listeria Enrichment broth (UVM) (Oxoid, Basingstoke, UK), and incubated at $30^{\circ} \mathrm{C}$ for $24 \mathrm{~h}$. One $\mathrm{mL}$ of the UVM broth was transferred to tubes containing $9 \mathrm{~mL}$ of Fraser broth (Oxoid, Basingstoke, UK), and incubated at $35^{\circ} \mathrm{C}$ for $24 \mathrm{~h}$. Samples that presented darkening were streaked on Modified 
Oxford agar (BD Diagnostic Systems, Franklin Lakes, NJ, USA) and incubated at $35^{\circ} \mathrm{C}$ for $24 \mathrm{~h}$. When Listeria typical colonies were present (small, grey to black, surrounded by blackening halo), they were submitted to identification by API-Listeria (bioMérieux S.A., Marcy l'Etoile, France). The final result was expressed as presence or absence of Listeria spp. in the sampled food or area (Table 1).

The autochthonous microbiota was determined by enumerating the following groups of microorganisms: mesophilic aerobes (MA), total coliforms (TC) and Escherichia coli (EC). From each sample, two decimal dilutions were selected and plated in Petrifilm ${ }^{\mathrm{TM}}$ plates (Petrifilm ${ }^{\mathrm{TM}} \mathrm{AC}$ for MA, and Petrifilm ${ }^{\mathrm{TM}} \mathrm{EC}$ for TC and EC) and incubated at $35^{\circ} \mathrm{C}$ for $24-48 \mathrm{~h}$. After incubation, the colonies formed in the plated area were enumerated and expressed as Colony Forming Units per gram or $\mathrm{cm}^{2}\left(\mathrm{CFU} / \mathrm{g}\right.$ or $\left.\mathrm{cm}^{2}\right)$.

\section{Data analysis}

For data analysis, the counts of MA, TC and EC were converted in $\log _{10}$. The numbers of Listeria spp positive samples according to the source (equipments, environments or products) and mean counts of MA, TC or EC were compared by Tukey Honest Significant Difference for unequal $n$, at a level of significance of 0.05 . The frequencies of positive and negative results for Listeria spp. were also calculated considering three levels of contamination by MA, TC and EC. All analyses were processed using the software Statistica 6.0 (StatSoft, Inc., Tulsa, OK, USA).

\section{RESULTS AND DISCUSSION}

One hundred and sixty seven samples were positive for Listeria spp: 76 samples from equipments, 23 from environments and 68 from products. The prevalence of species was as follows: L. innocua (131), L. monocytogenes (21), L. welshimeri (12), L. seeligeri (02) and L. grayi (01). Fig. 1 shows the positive and negative results for Listeria spp in the samples, the mean counts of MA, TC and EC, and the significance of the correlations between presence of Listeria spp and the counts of MA, TC and EC. The frequencies of positive or negative samples for Listeria spp. according to the levels of contamination by MA, TC and EC are shown in Figs. 2, 3 and 4, respectively.

In general, samples with positive results for Listeria spp. presented higher mean counts of indicators microorganisms than the Listeria spp. negative samples. In equipments, $44.7 \%$ of the Listeria spp. positive samples presented MA counts over $5 \log \mathrm{CFU} / \mathrm{cm}^{2}$, while in the environment Listeria spp. positive samples, this percentage was $73.9 \%$ and in products, $41.2 \%$. In the average, $47.3 \%$ of the Listeria spp. positive samples presented MA counts higher than $5 \log \mathrm{CFU} / \mathrm{cm}^{2}$, while for Listeria spp. negative samples this percentage was $24.3 \%$ (Fig. 2). The same situation was observed for total coliform

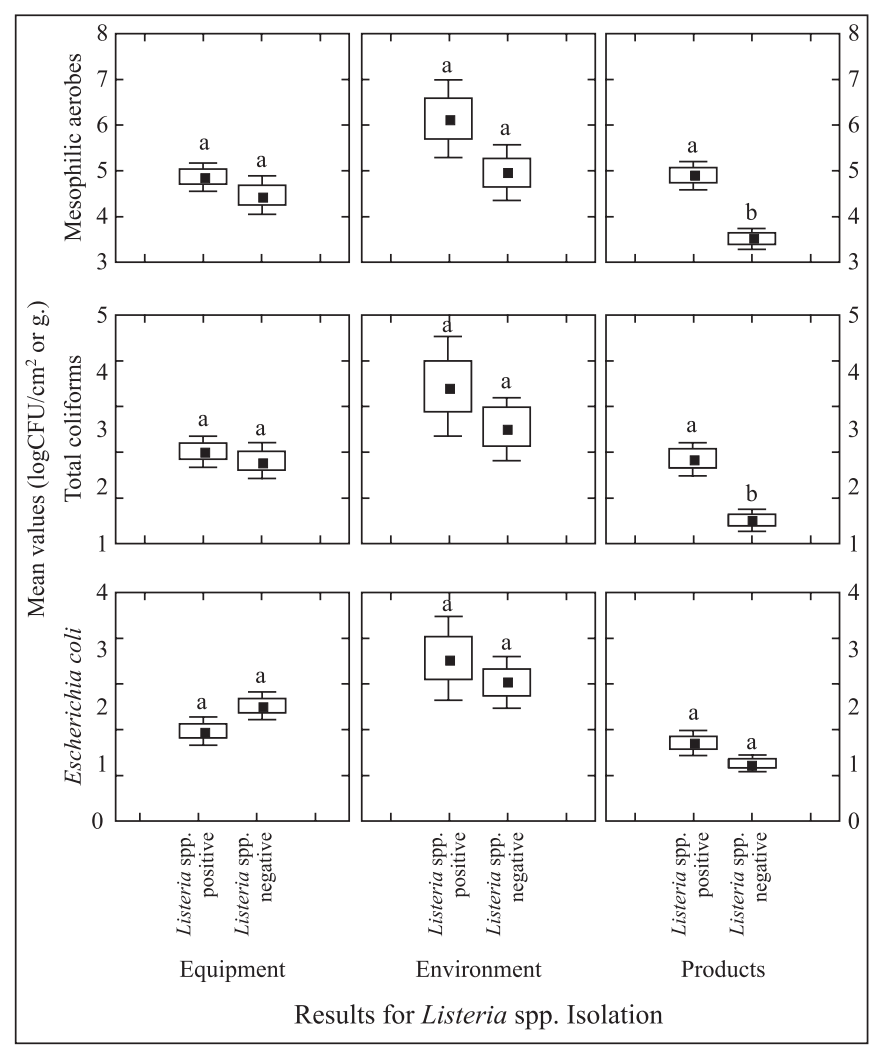

Figure 1. Counts of mesophilic aerobes, total coliforms and Escherichia coli and presence of Listeria spp. in samples collected from meat processing plants (equipment, environments and products). Distinct letters in each graph indicate significant difference $(\mathrm{P}<0.05)$.

counts (Fig. 3) and for E. coli (Fig. 4). All these differences were significant $(\mathrm{P}<0.05)$. However, it must be noted that for E.coli counts, the majority of results were lower than the limit of the detection method ( $2 \log \mathrm{CFU}$ per gram or $\mathrm{cm}^{2}$ ), so the significance of the differences between Listeria spp. positive and negative results could not be calculated properly.

These results suggest that the autochthonous microbiota in meat products and meat processing environment did not affect the survival or growth of Listeria spp. in them. The possible interferences of the autochthonous food microbiota over Listeria spp. and L. monocytogenes are widely variable due to several factors, including microbiological composition, preserving temperatures and inhibitory substances production. A common microorganism present in meat and meat processing plants, Pseudomonas fluorescens, was already described as improving (22), inhibiting (4) and causing no effect (8) on $L$. monocytogenes growth. Those distinct behaviors of food accompanying microbiota were also observed by Buchanan and Bagi (2). 


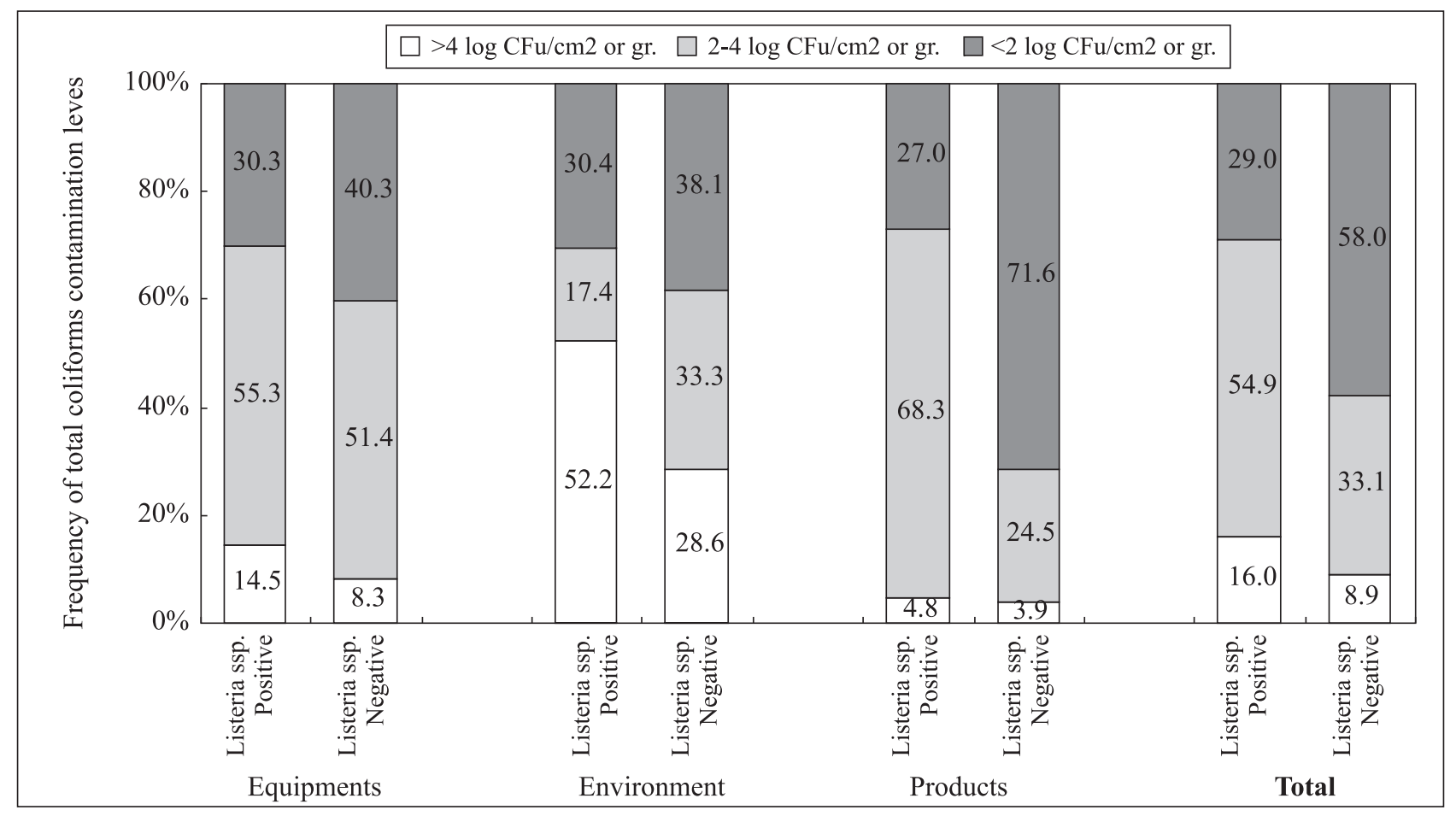

Figure 2. Occurrence of Listeria spp in meat products and equipment and environmental samples collected in meat processing plants located in Londrina region, Paraná State, PR, Brazil, according to the contamination level by mesophilic aerobes.

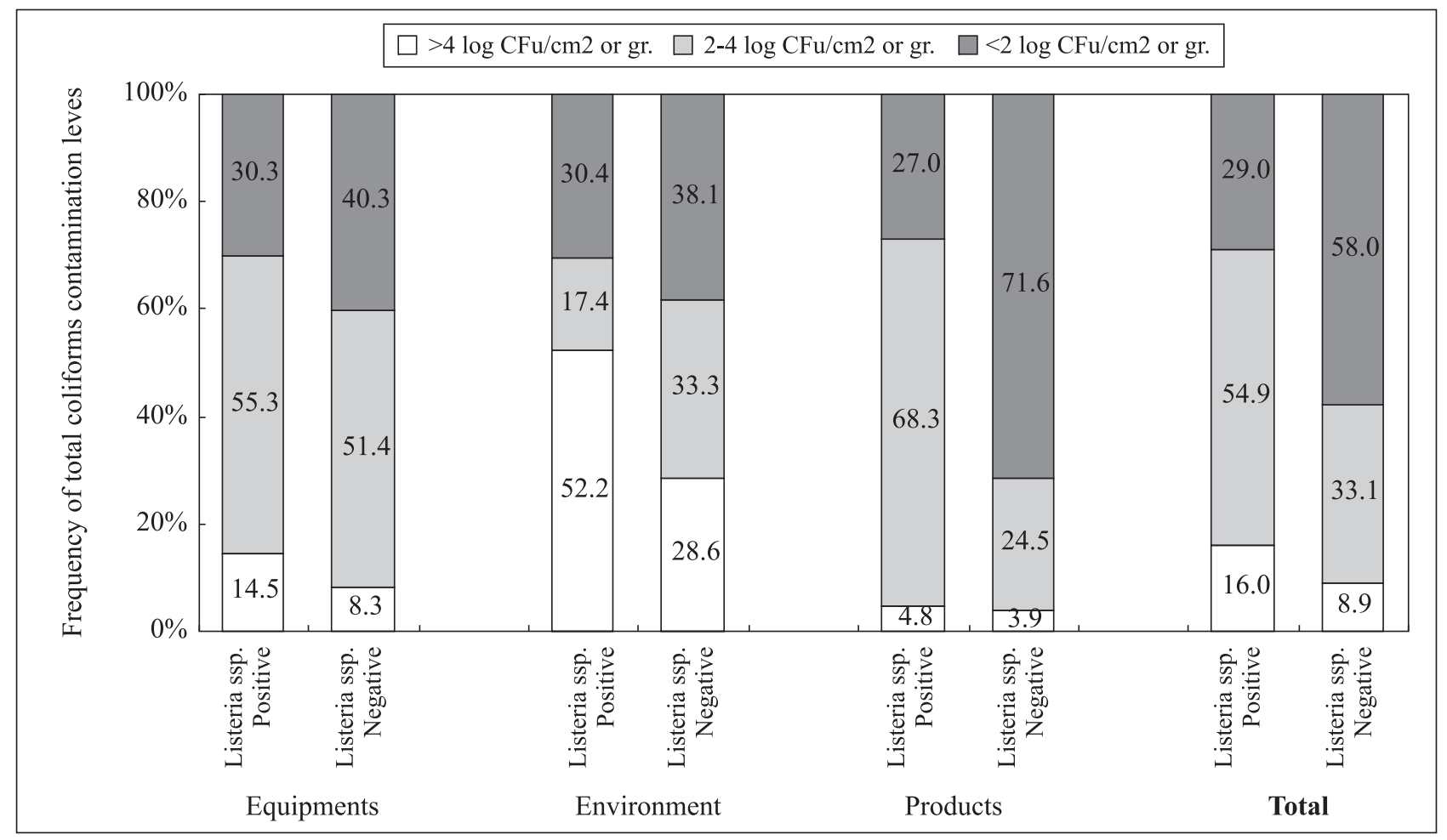

Figure 3. Occurrence of Listeria spp in meat products and equipment and environmental samples collected in meat processing plants located in Londrina region, Paraná State, PR, Brazil, according to the contamination level by total coliforms. 


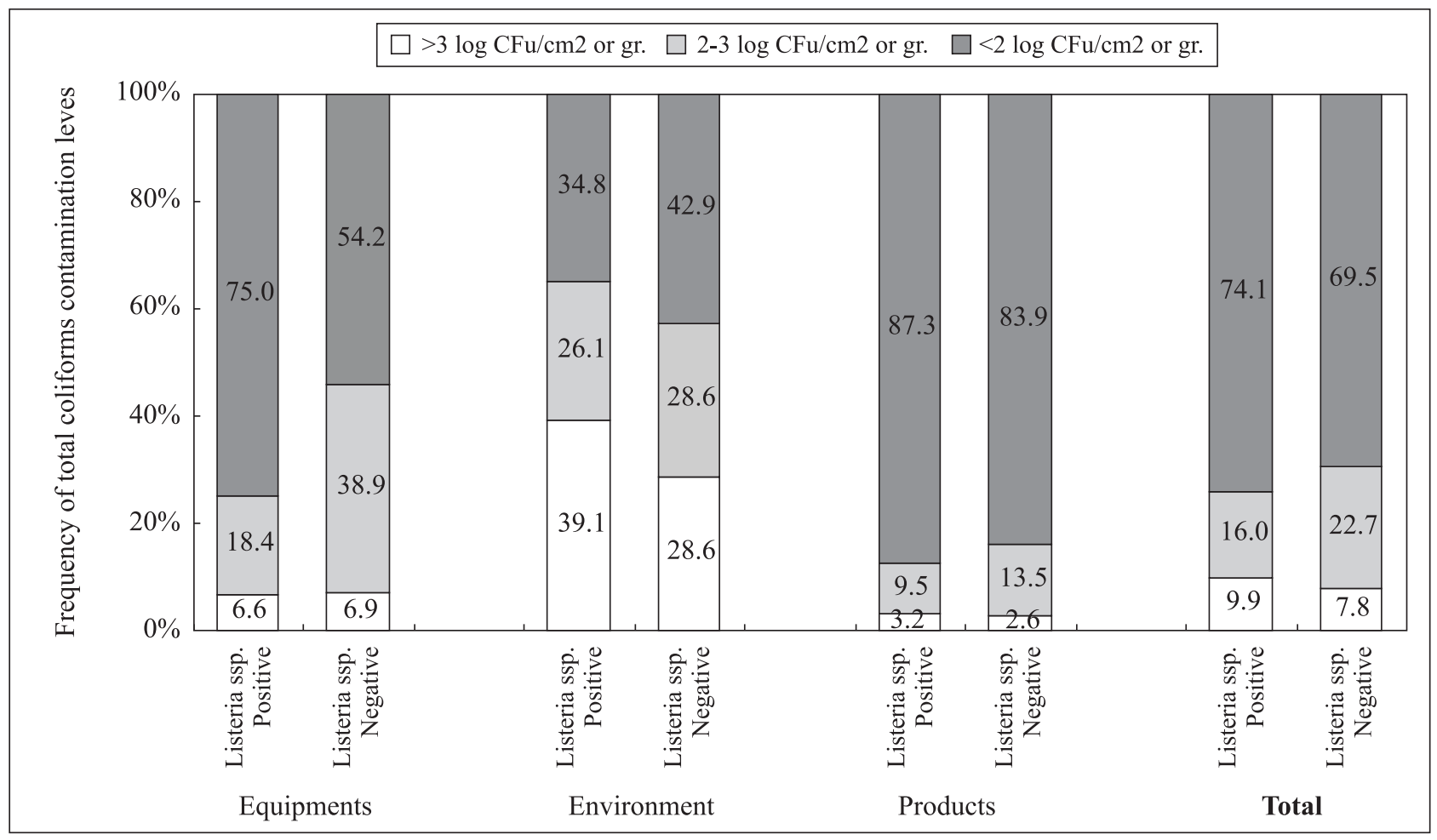

Figure 4. Occurrence of Listeria spp in meat products and equipment and environmental samples collected in meat processing plants located in Londrina region, Paraná State, PR, Brazil, according to the contamination level by Escherichia coli.

According to Jay $(15,16)$, fresh meats with MA counts between $10^{4}$ and $10^{6} \mathrm{CFU} / \mathrm{g}$ are probably not vehicles of foodborne pathogens, due the autochthonous presence of inhibitory microorganisms. However, the results of the present study indicate that even at these levels the isolation of Listeria spp., including the pathogenic specie L. monocytogenes, is possible.

The utilization of UVM broth in the enrichment step may explain the absence of interference of the autochthonous microbiota of the meat products on the isolation of Listeria spp. This culture media is known as the most suitable to isolate Listeria spp. in foods with high levels of microbiological contamination, due to its effective inhibitory activity by the added supplements $(19,30)$. Some authors even suggest that UVM promotes a better recovery of $L$. innocua than $L$. monocytogenes $(5,26)$, especially due to a higher growth velocity of the first (21). However, Duffy et al. (6) demonstrated that this culture media did not promote significant differences in the recovery of both Listeria species.

In food processing surfaces and utensils, a contamination level of $10^{4} \mathrm{CFU} / \mathrm{cm}^{2}$ is considered enough to begin biofilm formation (13). In this study, several samples presented counts higher than $10^{4} \mathrm{CFU} / \mathrm{cm}^{2}$, suggesting the possibility of biofilm formation on equipment surfaces, and even in products. The importance of these findings is relevant because these contamination levels were found in several Listeria spp. positive samples. The literature reports studies indicating that $L$. monocytogenes is able to grow and some autochthonous strains, such as Flavobacterium spp., can even improve its development (17). Listeria spp. are able to produce glycocalyx in stainless steel surfaces within $48 \mathrm{~h}$, promoting self protection against environmental microorganisms that can produce inhibitory substances $(14,33)$.

In conclusion, the results of the present study suggest that the autochthonous microbiota of meat and meat processing plants have very little, if any, influence on the isolation of Listeria spp., even when the counts of hygiene indicator microorganisms surpass $5 \mathrm{log} \mathrm{CFU} / \mathrm{cm}^{2}$ or $\mathrm{g}$. The official methodology for the isolation of Listeria spp from meat and equipment surfaces was shown to be appropriate, with no interference of the autochthonous microbiota.

\section{RESUMO}

\section{Listeria spp. associado a diferentes níveis da microbiota autóctone de carne, produtos cárneos e plantas de processamento}

Altos níveis de contaminação microbiana, usualmente encontrados em alimentos de origem animal e nos ambientes de 
processamento, podem inibir a multiplicação de microrganismos patogênicos nesses produtos e interferir nos resultados das análises laboratoriais para o isolamento desses patógenos. Com o objetivo de verificar as possíveis interferências da microbiota autóctone encontrada na carne, produtos cárneos e plantas de processamento sobre a presença de Listeria spp., 443 amostras, coletadas em 11 estabelecimentos processadores, foram submetidas a análises microbiológicas para determinação dos níveis de contaminação por aeróbios mesófilos, coliformes totais e Escherichia coli e para verificação da presença de Listeria spp., de acordo com a metodologia proposta pelo USDA. Os resultados obtidos não mostraram uma interferência evidente da microbiota autóctone sobre Listeria spp., uma vez que esse gênero foi detectado mesmo nas amostras de carne e produtos cárneos e amostras ambientais e de superfície de equipamentos que apresentaram altos níveis de contaminação por aeróbios mesófilos e coliformes.

Palavras-chave: carne, Listeria spp.; microbiota autóctone

\section{REFERENCES}

1. Bagge-Ravn, D.; NG, Y.; Hjelm, M.; Christiansen, J.N.; Johansen, C.; Gram, L. (2003). The microbial ecology of processing equipment in different fish industries-analysis of the microflora during processing and following cleaning and disinfection. Int. J. Food Microbiol., 87: 239-250.

2. Buchanan, R.L.; Bagi, L.K. (1999). Microbial competition: effect of Pseudomonas fluorescens on the growth of Listeria monocytogenes. Food Microbiol., 16: 523-529.

3. Bula, C.; Bille, J.; Mean, F. (1989). Epidemic foodborne listeriosis in western Switzerland. I. Description of the 58 adult cases. $28^{\text {th }}$ Interscience Conference on Antimicrobial Agents and Chemotherapy, Washington D.C, p.35.

4. Cheng, C.-M.; Doyle, M.P.; Luchansky, J.B. (1995). Identification of Pseudomonas fluorescens strains isolated from raw pork and chicken that produce siderophores antagonistic towards foodborne pathogens. J. Food Prot., 58: 1340-1344.

5. Curiale, M.S.; Lewus, C. (1994). Detection of Listeria monocytogenes in samples containing Listeria innocua. J. Food Prot., 57: 10481051.

6. Duffy, G.; Walsh, D.; Sheridan, J.J.; Logue, C.M.; Harrington, D.; Blair, I.C.; McDowell, D.A. (2001). Comparison of selective and non-selective enrichment media in the detection of Listeria monocytogenes from meat containing Listeria innocua. J. Appl. Microbiol., 90: 994-999.

7. Farber, T.M.; Peterkin, P.I. (1991). Listeria monocytogenes, a foodborne pathogen. Microbiol. Rev., 55: 476-511.

8. Farrag, S.A.; Marth, E.H. (1989). Variation in initial populations of Pseudomonas fluorescens affectes behaviour of Listeria monocytogenes in skim milk at 7 or $13^{\circ} \mathrm{C}$. Milchwissenschaft, 46 : 718-721.

9. Franco, B.D.G.M.; Landgraf, M.; Destro, M.T.; Gelli, D. (2003). Foodborne diseases in Southern South América. In: Miliotis, M.; Bier, J. (ed) International Handbook of Foodborne Pathogens. Marcel Dekker, New York, p.733-743.

10. Frank, J.F.; Koffi, R.A. (1990). Surface-adherent growth of Listeria monocytogenes is associated with increased resistance to surfactant sanitizers and heat. J. Food Prot., 53: 550-554.
11. Hofer, E.; Nascimento, R.S.; Oliveira, M.A. (1998). Meningite por Listeria monocytogenes. Relato de casos em pacientes do Distrito Federal. Rev. Soc. Bras. Med. Trop., 31: 173-177.

12. Hofer, C.B.; Melles, C.E.A.; Hofer, E. (1999). Listeria monocytogenes in renal transplant recipients. Rev. Inst. Med. Trop. São Paulo, 41: 375-377.

13. Hood, S.K.; Zottola, E.A. (1995). Biofilms in food processing. Food Control, 6: 9-18.

14. Hoyle, B.D. (1990). The biofilm glycocalyx as a resistance factor. $J$. Antimicrob. Chemothe., 26: 1-6.

15. Jay, J.M. (1995). "Foods with low numbers of microorganisms may not be the safest foods" or "Why did human listeriosis and hemorrhagic colitis become foodborne diseases?" Dairy Food Environ. Sanit., 15: 674-677.

16. Jay, J.M. (1996). Microorganisms in fresh ground meats: the relative safety of products with low versus high numbers. Meat Sci., 43: 5966.

17. Jeong, D.K.; Frank, J.F. (1994). Growth of Listeria monocytogenes at $21^{\circ} \mathrm{C}$ in biofilms with microorganisms isolated from meat and dairy processing environments. Lebensm. Wiss. Technol., 27: 415424.

18. Leriche, V.; Carpentier, B. (2000). Limitation of adhesion and growth of Listeria monocytogenes on stainless steel surfaces by Staphylococcus sciuri biofilms. J. Appl. Microbiol., 88: 594-605.

19. Lewis, S.J.; Corry, J.E.L. (1991). Comparison of a cold enrichment and the FDA method for isolating Listeria monocytogenes and other Listeria spp. from ready to eat food on retail sale in the U.K. Int. J. Food Microbiol., 12: 281-286.

20. Linnan, M.J.; Mascola, L.; Lou, X.D. (1998). Epidemic listeriosis associated with Mexican-style cheese. N. Engl. J. Med., 319: 823828.

21. MacDonald, F.; Sutherland, A.D. (1994). Important differences between the generation times of Listeria monocytogenes and Listeria innocua in two Listeria enrichment broths. J. Dairy Res., 61: 433436.

22. Marshall, D.L.; Andrews, L.S.; Wells, J.H.; Farr, A.J. (1992). Influence of modified atmosphere packaging on the competitive growth of Listeria monocytogenes and Pseudomonas fluorescens on precooked chicken. Food Microbiol., 9: 303-309.

23. Møretrø, T.; Langsrud, S. (2004). Listeria monocytogenes: biofilm formation and persistence in food-processing environments. Biofilms, 1: $107-121$.

24. Nero, L.A.; Mattos, M.R.; Beloti, V.; Barros, M.A.F.; Pontes-Netto, D.; Nogueira Pinto, J.P.A.; Andrade, N.J.; Silva, W.P.; Franco, D.D.G.M. (2004). Hazards in non-pasteurized milk on retail sale in Brazil: prevalence of Listeria monocytogenes, Salmonella spp. and chemical residues. Braz. J. Microbiol., 35: 211-215.

25. Nørrung, B.; Sølve, M.; Ovesen, M.; Skovgaard, N. (1991). Evaluation of an ELISA test for detection of Listeria spp. J. Food Prot., 54: 174-177.

26. Petran, R.L.; Swanson, K.M.J. (1993). Simultaneous growth of Listeria monocytogenes and Listeria innocua. J. Food Prot., 56: 616-618.

27. Ryser, E.T.; Arimi, S.M.; Bunduki, M.C.M.; Donnely, C.W. (1996). Recovery of different Listeria ribotypes from naturally contamined, raw refrigerated meat and poultry products with two primary enrichment medias. Appl. Environ. Microbiol., 62: 17811787.

28. Schlech, W.F.; Lavigne, P.M.; Bortolussi, R.A.; Allen, A.C.; Haldane, E.V.; Wort, A.J.; Hightower, A.W.; Johnson, S.E.; King, S.H.; Nicholls, E.S.; Broome, C.V. (1983). Epidemic listeriosis-evidence for transmission by food. N. Engl. J. Med., 308: 203-206.

29. Schuchat, A.; Deaver, K.; Ger, J.D. (1992). Role of foods in sporadic listeriosis. I. Case control study of dietary risk factors. J. Am. Med. Assoc., 267: 2041-2045. 
30. Slade, P.J. (1992). Monitoring Listeria in the food production environment. I. Detection of Listeria in processing plants and isolation methodology. Food Res. Intern., 25: 45-56.

31. Suh, J.H.; Knabel, S.J. (2001). Comparison of different enrichment broths and background flora for detection of heat-injured Listeria monocytogenes in whole milk. J. Food Prot., 64: 30-36.
32. United States Department of Agriculture. Food Safety and Inspection Service. (1996). Pathogen Reduction/ Hazard Analysis and Critical Control Point (HACCP) Systems/Specific Sample Collection Procedure CRF Part 304, Rules and Regulations 38931, 61:144.

33. Wirtanen, G.; Mattila-Sandholm, T. (1992). Effect of the growth phase of foodborne biofilms on their resistance to chlorine sanitizer, Part II. Lebensm. Wiss. Technol., 25: 50-54. 